\title{
Characterizing UNAM's Open Education System Using the OOFAT Model
}

Francisco Cervantes-Perez, Guadalupe Vadillo, Jackeline Bucio, and Alma Herrera Universidad Nacional Autónoma de México

\begin{abstract}
Mexico's national university (UNAM) is a public mega university with a 46-year history in open education. This article presents an analysis based on the open, online, flexible provision of technologyenhanced higher education (OOFAT) model, developed by Orr and his colleagues (2018). The aim of this analysis was to characterize UNAM's open and distance education system in terms of openness, flexibility, and its business model, in three distinct time periods. According to this analysis, the system has evolved in all areas, and at present has a content-focused approach in terms of flexibility and openness, which differs from the OOFAT at the center approach that is desired. The study also characterized the UNAM system's business model as a prospector-like approach, which highlights the possibilities for instilling innovation through the schools that comprise this system. The analysis allowed for mapping the current situation and thus sheds light on defining the steps necessary for creating an integrally open system.
\end{abstract}

Keywords: openness, flexibility, Mexico, UNAM, future of education, OOFAT model 


\section{Introduction}

The purpose of this article is to analyse the evolution of openness and flexibility in three important moments of the Open University and Distance Education System (SUAyED) at Universidad Nacional Autónoma de México (UNAM), by applying the OOFAT (open, online, flexible provision of technologyenhanced higher education) model developed by Orr, Weller, and Farrow (2018). The aim is to identify strengths, weaknesses, and opportunities that might indicate the system's future developments.

\section{History of the Open and Distance Education System at UNAM}

UNAM a is public mega university (in terms of Berberoğlu \& Berberoğlu, 2015) currently serving almost 350,000 students at the high school, undergraduate, and graduate levels. Of these, 32,000 are enrolled in open or distance programs. The origins of the SUAyED at UNAM can be traced back to the late 1960s when the political environment in Mexico as well as inside the university was in a deep turmoil. This situation inspired the design of innovative public educational models in order to foster inclusion and increased access to higher education (HE). In 1972, Dr. Pablo González Casanova, UNAM's president at the time, launched the Open University System (SUA), with a clear emphasis on academic quality and providing access for those who wanted to pursue educational programs but could not attend a brickand-mortar classroom (González-Casanova, 1972). The main purpose was to open the university to any interested individual who passed the admission exam, in groups that met at workplaces and cultural centers throughout the country (Gaceta UNAM, 1972; Universidad Nacional Autónoma de México [UNAM], 1983). This was a democratizing strategy that followed the steps of successful projects in other nations (Bosco \& Barrón, 2008).

Due to the evolution of the term open, and to the changes to UNAM's open system over the years, the use of this term may be confusing. In 1972, and even today, the term open was institutionally conceived as alternatives to students' opportunity to attend face-to-face (F2F) classes only a few times a week, mainly on weekends, in order to solve problems, clarify their doubts, and prepare for exams. The concept of open represented a chance to attend fewer sessions than F2F classes, while still following the same academic program and semester calendar of traditional offerings. The new system also implied changes in the interaction of students and teachers. High quality resources, the use of media, and a dynamic dialogue among students were to create a learning context in which evaluation was objective and rigorous, and self-management strategies were encouraged. Procedures and professional development programs for teachers were developed. In the 20 years following 1972, the system matured and also benefited from facing challenges and accomplishing goals. Several university presidents fostered UNAM's growth through programs, projects, and infrastructure. To celebrate its 20th anniversary, an international conference was organized in order to evaluate the experience and identify the perspectives for the development not only of open education but also of distance learning at UNAM (Sarukhán, 1992).

In 1997, a new office to coordinate the open university and distance education (CUAED) was established at UNAM. In 2009, new internal bylaws allowed for a complete SUAyED to be formally organized. The idea was to extend high school and HE to broad sectors of the Mexican population, through including information and communication technology (ICT) and organizing study groups on and off the physical campus (Coordinación de Universidad Abierta y Educación a Distancia, n.d.). In this way, the initial Open University System (SUA) evolved to become the Open and Distance Education System, that includes online education programs with content provided through online platforms where students, teachers, and peers communicate online. The term open, in this case, refers to the space (anytime, 
anywhere), and to the content (materials, learning and assessment activities, and readings), although there still exists an academic calendar to follow. Some blended programs have been developed as well.

SUAyED currently serves nearly 32,000 students through 59 academic programs, representing around $10 \%$ of UNAM's total student population (Universidad Nacional Autónoma de México [UNAM], 2018). At present there are 23 open undergraduate programs and 21 online undergraduate programs, as well as an online high school, 10 online graduate programs, and 4 open graduate programs (Coordinación de Universidad Abierta y Educación a Distancia [CUAED], n.d.). Open and distance education has become increasingly important at the institutional level, especially because of its contribution to expanding enrolment and its ability to enrich F2F education. In the university's 2015- 2019 institutional plan, for example, 13 out of 17 strategic programs involve actions under the responsibility of CUAED and SUAyED (Graue, 2017).

\section{The OOFAT Model}

This section describes the OOFAT model, in order to better explain the methodology of this study. Orr et al. (2018) used as three core processes of HE as the basis for their model: (a) content (subject knowledge, support and guidance, and learning analytics); (b) delivery (qualities of place, pace, and timing of delivery of content); and (c) recognition (assessment and credentialization to recognize learning achievements). Each of these processes is evaluated in terms of organizational flexibility (the way in which digital technology is used to reduce the need for physical presence and the possibility of adapting given specific circumstances) and procedural openness (inclusion or how the principle of openness is integrated into the core processes).

Orr et al. (2018) conducted a global survey in February 2017. They collected data from $69 \mathrm{HE}$ institutions in 36 countries. With this information, they developed six major typologies (see Orr et al., p. 10):

- OOFAT at the centre: the model is implemented as an integral part of the institution's overall mission.

- OOFAT for organizational flexibility: OOFAT supports flexibility of higher education provision across all aspects of the conceptual model.

- Content-focused OOFAT: providers concentrate specifically on the element of content development and delivery.

- Access-focused OOFAT: providers focus on access to content and support

- OOFAT for a specific purpose: implementation of the model is geared to a very specific function or market.

- OOFAT for multiple-projects: there is no unified strategy, but rather the provider undertakes very different initiatives and experiments with different aspects of the OOFAT model. This was the most frequent category in their study, evident in 28 of the 69 institutions. 
Orr et al. (2018) also studied institutions' business models by analyzing the seven coreaspects originally proposed by Taran, Boer, and Lindgren (2015, as cited in Orr et al., 2018) in their typology. These core aspects include: (a) products and services, (b) target group, (c) communication channels, (d) legacy or new value chain, (e) competitive advantage, (f) networks, and (g) profitability and sustainability. Orr et al. asked respondents to characterize their business models by choosing one of two response options within each aspect. Their first option focused on developing existing activities and the second option on breaking into new markets (see Orr et al., pp. 33-34).

Orr et al. (2018) classified business strategies into two groups. The first group is described as defenderlike strategies, and includes three specific strategies:

- Fixed-core model: more traditional in terms of target market, and products and services, but innovating in other areas. This was the most frequent selection in their study.

- Outreach model: using the same products and services but innovating in target group recruiting and communication channels.

- Service-provider model: focusing on the target group and innovating in communication, and products and services.

The second group is described as prospector-like, and includes two main strategies:

- Entrepreneurial model: with innovative strategies for products and services, target group, and communication.

- Entrepreneurial model with fixed core: the strategy is focussed on a fixed core, but innovation is built around it.

Orr et al. (2018) delivered their OOFAT questionnaire via Survey Monkey, and it was answered by any individual who received the instrument and decided to collaborate. This could have created disadvantages for some universities, which may have been underrepresented. For instance, in the case of a UNAM, only a representative from the School of Chemistry participated in the survey. This respondent provided data that exclusive to that school's context, rather than the open and distance education system of the entire university. For this reason, this article complements the comparative analysis made by Orr et al.

The 6 typologies and the business strategies may lead to:

The formulation and effective implementation of comprehensive institutional strategies, which provide clear focal points for where a university or college has chosen to integrate digitalisation into its key processes. HEIs can use the typologies developed in this study either to determine their current position or to decide which type of model they aspire to [emphasis added]. (Orr et al., 2018, p. 12)

With that purpose in mind, this study applied the OOFAT model in order to analyze the state of openness and flexibility within three important moments in the evolution of open and distance education at UNAM. 


\section{Methodology}

The purpose of this study was to identify the openness and flexibility of SUAyED throughout a period of 48 years, in order to visualize both their evolution and current state. This will help determine the model CUAED is aiming for in the near future.

The selected model for this analysis was OOFAT (Orr et al., 2018). This choice was made for two main reasons: first, because it facilitates the visualization of the state of openness and flexibility in educational programs, and second, because this analysis will complement the efforts initiated by Orr et al. (2018) with the goal of mapping the state of openness in educational institutions all over the world. Due to the fact that CUAED is an institution aimed at social inclusion and justice, a model based on openness and flexibility constitutes a good match.

Four knowledgeable reviewers were selected to evaluate openness and flexibility of SUAyED in three distinct periods of its evolution: (a) 1972, when the open education system was introduced; (b) 2005, when the first online HE programs were deployed; and (c) 2018, when the assessment took place.

One of the reviewers (A) has been the researcher most committed to the study of the history and evolution of SUAyED, and a second (B) has been the director of CUAED. The remaining two (C and D) held important positions at CUAED at the time of the study. Collectively, they represent 74 years of experience in the open and distance education field.

The study entailed three stages. The first stage, the openness and flexibility analysis consisted of the following steps:

1. Each reviewer was asked to complete the OOFAT tool: reviewer A evaluated the years 1972 to 2005, while reviewers B, C, and D evaluated 2018. Then, each reviewer received the questionnaire, in order to assess the nine areas they were to evaluate. This handout included further description of the content of the question and an example of what it meant to have a low or a high evaluation in each item (see Orr et al., 2018, pp. 46-47).

2. For the 2018 final score, the mean of each rating by the three reviewers in charge of evaluating that period was calculated for each question.

3. The results of the three periods were plotted on the OOFAT graph.

4. The resulting graphs were then compared to the six models presented by Orr et al. (2018) in order to identify the best fit for each of the three periods that were analyzed.

The second stage of the study addressed the topic of UNAM's business model. Reviewers B, C, and D defined the type of core aspects of the institution, using the modified typology from Taran, Boer, and Lindgren (2015, as cited in Orr et al., 2018).

The third stage addressed planning. Based on the results of the first two stages, the type of OOFAT and business model for SUAyED were defined, and the actions and elements needed to achieve them were identified. 


\section{Results}

\section{Openness and Flexibility Models}

Table 1 shows the evaluation in three historical moments: (a) 1972, when SUA was created; (b) 2005, when online undergraduate programs were first launched; and (c) 2018 for the present time.

Table 1

OOFAT Historical Analysis of SUAyED's Pivotal Transformations

\begin{tabular}{lccc}
\hline \multicolumn{1}{c}{ OOFAT dimension } & $\begin{array}{c}\text { 1972: Creation of the } \\
\text { Open University System }\end{array}$ & $\begin{array}{c}\text { 2005: First distance } \\
\text { programs }\end{array}$ & 2018 \\
\hline Content delivery: flexible & 1 & 4 & 3.5 \\
Content delivery: open & 1 & 3.5 & 3.8 \\
Support delivery: flexible & 1 & 3 & 4.2 \\
Support delivery: open & 1 & 3 & 3.2 \\
Content personalization & 1 & 3 & 2.2 \\
Content production: open & 1 & 3 & 3.1 \\
Assessment: flexible & 1 & 1 & 2.2 \\
Formal recognition: flexible & 1 & 1 & 2.2 \\
Recognition: open & 1 & 1 & 57.8 \\
Total & 9 & 22.5 & \\
\hline
\end{tabular}

As can be seen in Table 1, the SUAyED system has evolved over its 46-year history. In the beginning, there was practically no openness or flexibility in the areas of content, support, and recognition. As time went by, increasing scores demonstrate the progress of the system's evolution. Figure 1 illustrates the evaluation of the three moments that were considered. Blue lines represent 1972, purple lines represent 2005, and red lines correspond to 2018. Current strengths are in bold, green text, while weaknesses are in blue text. 


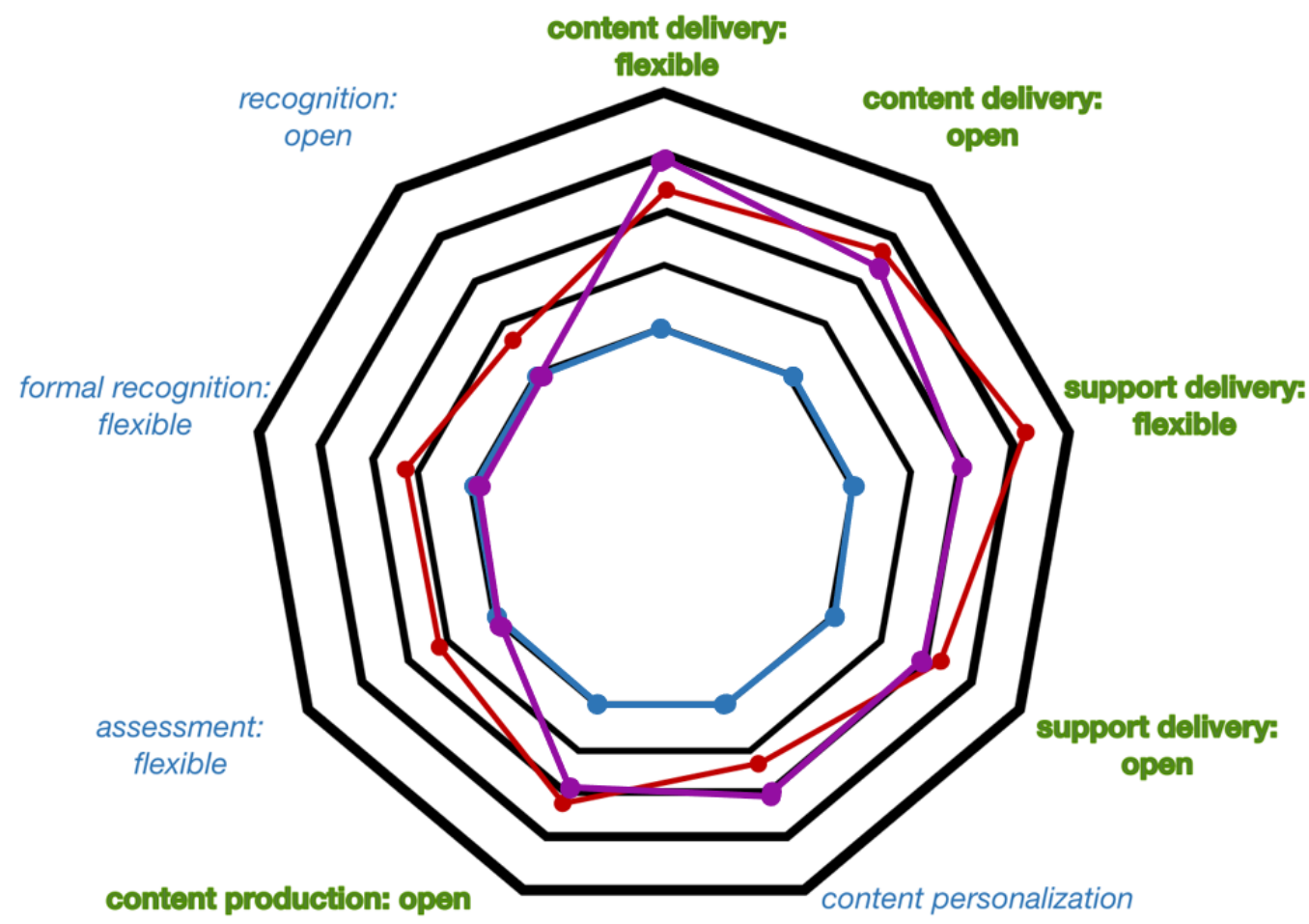

Figure 1. OOFAT analysis of UNAM's SUAyED offerings.

This analysis reveals that CUAED follows a content-focused approach. CUAED has advanced in aspects such as content delivery, content production, and content support, while in other aspects such as assessment flexibility, content personalization, and recognition, continued work is still necessary. These results were compared with those of the other universities. Orr et al.'s analysis (2018) indicated that other institutions following this approach include: (a) Indira Gandhi National Open University (IGNOU) in India; (b) National Open University of Nigeria (NOUN); (c) University of Rwanda; (d) Hamdan Bin Mohammed Smart University (HBMSU); (e) United Arab Emirates; and (f) The University of Warwick, UK.

\section{Business Model}

Regarding the business model, it was clear that UNAM, as a whole, follows a defender-like approach; it is a traditional institution that follows conservative procedures and guidelines. On the other hand, SUAyED (representing 19 schools in UNAM) clearly follows a prospector-like approach, due to its digital nature and innovative educational initiatives. Table 2 shows how the core aspects proposed by Orr et al. (2018) align with the SUAyED initiatives that correspond to this prospector-like approach. The examples in the second column come from "dimensions of the business model: prospector-like approach" (Orr et al., 2018, pp. 33- 34). 
Table 2

SUAyED Initiatives (Products, Services, and Projects) That Correspond to the Prospector-Like Approach

\begin{tabular}{|c|c|c|}
\hline Core aspects & Prospector-like approach & SUAyED initiatives \\
\hline $\begin{array}{l}\text { Products and } \\
\text { services }\end{array}$ & $\begin{array}{l}\text { We offer something different, } \\
\text { complementary or alternative to the } \\
\text { main provision. }\end{array}$ & $\begin{array}{l}\text { Perseo } \\
\text { Who's who } \\
\text { English as a second language } \\
\text { Coding }\end{array}$ \\
\hline Target group & $\begin{array}{l}\text { We are targeting a new (or non- } \\
\text { traditional) market. }\end{array}$ & $\begin{array}{l}\text { MOOC } \\
\text { Pre-UNAM communities } \\
\text { Increasing share of young learners }\end{array}$ \\
\hline $\begin{array}{l}\text { Communication } \\
\text { channels }\end{array}$ & $\begin{array}{l}\text { We interact with learners through } \\
\text { new or innovative relationship } \\
\text { channels (physical or virtual). }\end{array}$ & $\begin{array}{l}\text { Online counselling service } \\
\text { B@UNAM as innovation hub } \\
\text { Matcha }\end{array}$ \\
\hline $\begin{array}{l}\text { Legacy or new } \\
\text { value chain }\end{array}$ & $\begin{array}{l}\text { We develop, produce, and maintain } \\
\text { our offering through exploration of } \\
\text { new approaches and innovation. }\end{array}$ & $\begin{array}{l}\text { Trajectories } \\
\text { UAPAs } \\
\text { B@UNAM as innovation hub }\end{array}$ \\
\hline $\begin{array}{l}\text { Competitive } \\
\text { advantage }\end{array}$ & $\begin{array}{l}\text { Our competitive advantage comes } \\
\text { from new, unfamiliar competences } \\
\text { (e.g., new or emerging technologies, } \\
\text { innovation in working practices). }\end{array}$ & $\begin{array}{l}\text { Artificial intelligence (AI) } \\
\text { Lego model }\end{array}$ \\
\hline Networks & $\begin{array}{l}\text { We operate primarily in non- } \\
\text { traditional or (dynamic) networks } \\
\text { (e.g., alliance, joint-venture). }\end{array}$ & $\begin{array}{l}\text { Coursera } \\
\text { Ceibal Foundation-ANII } \\
\text { Revista Mexicana de Bachillerato a } \\
\text { Distancia } \\
\text { NGO ("J untos en línea”) }\end{array}$ \\
\hline $\begin{array}{l}\text { Profitability and } \\
\text { sustainability }\end{array}$ & $\begin{array}{l}\text { We maintain profitability through } \\
\text { new processes to generate revenues, } \\
\text { or cost-cutting in existing processes. }\end{array}$ & $\begin{array}{l}\text { Ministries of Education } \\
\text { Mexico City's government } \\
\text { Private schools } \\
\text { Professional development courses }\end{array}$ \\
\hline
\end{tabular}

Note. Descriptions of the prospector-like approach comes from Orr et al., 2018.

Specific SUAyED initiatives are described below.

Products and services. Some initiatives that reflect the way SUAyED offers something new, complementary, and different from the traditional provision include: 
- Prerequisite programs. At both at the high school and university levels $s^{i}$ these programs have a selective and a formative purpose. Applicants must comply with all academic requirements in order to enter the programs, but they also develop digital literacy and acquire knowledge about themselves as learners. For example, at B@UNAM learners identify their level of reading speed as well as their reading comprehension, as related to their age and educational level, and work to develop and improve those skills. At the HE level, they enter the PERSEO system ${ }^{\mathrm{ii}}$ that consists of a series of tests and questionnaires to identify cognitive strengths and learning risk factors (Herrera, Díaz, Soto, Vázquez, \& Cervantes, 2018). Qualitative mechanisms are also available, such as a document called Who's who that counsellors at the high school level develop for each individual student. This clarifies the learner's strengths and weaknesses, as well as the type of educational interventions that have been successful for that individual. Counsellors share this document with tutors in order to improve their knowledge about each learner and tailor their interventions to suit each one's needs.

- Pre-university communities. In order to help ensure high school graduates are ready to enter specific undergraduate programs, several sites have been developed to prepare freshmen for the challenges of college education, by using B@UNAM materials. These include diagnostic tests to identify content information learners lack, and courses to improve their knowledge in those areas. The first one was the Pre-Med Communityiii (Vadillo, Macedo, \& Terrazas, 2017).

- No tuition fees. There are no tuition fees for UNAM students in the high school or HE programs. This contributes to an institutional-wide acceptance of openness.

The complete entrance process of this support program is shown in Figure 2.

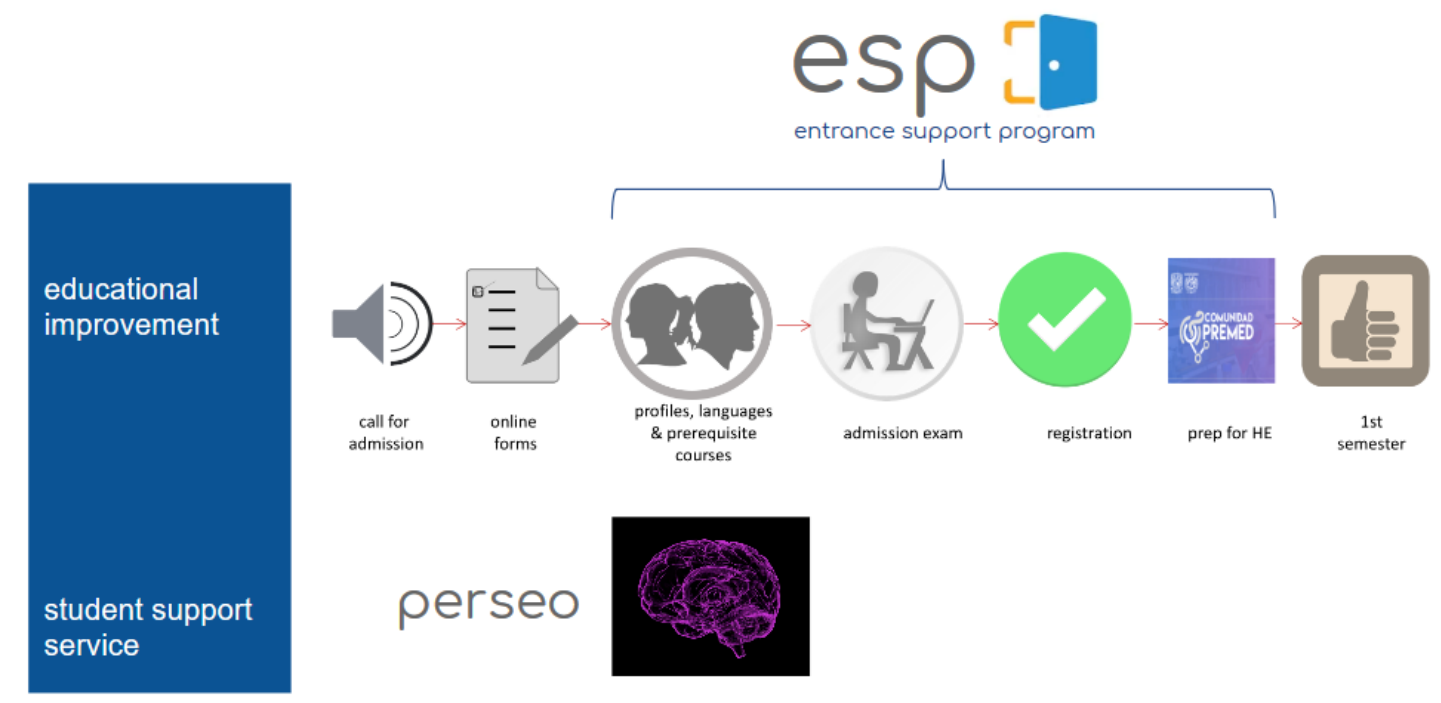

Figure 2. Entrance support process for candidates seeking entrance to undergraduate programs. Source: Own elaboration.

Target group. The most important initiative that exemplifies new or non-traditional markets is the massive open online course (MOOC) catalogue. To date, there are $78 \mathrm{MOOCs}^{\mathrm{iv}}$ and 8 specialization programs. This initiative has enabled UNAM to reach students in 194 countries around the world (J. 
Maggioncalda, personal communication, November 18, 2018). Over 1.9 million students have registered, representing more than a million unique persons. They constitute a diverse population in terms of age, academic background, ethnicity, socioeconomic status, and reasons for enrolling in these courses.

In association with Mexico City's government, a blended high school was established in a poor and high crimeneighborhood (Ruiz, Peláez, \&Madrigal, 2015; Sabath, García, \&González, 2016). Due to political reasons, the only public high school in the area was closed and for more than 40 years there was no facility to serve the local population. The blended school used B@UNAM's online materials.

Another new target group consists of high school graduates and college freshmen who are not B@UNAM learners but benefit from the diagnostic tests and remedial courses in the HE schools that have the pre-university communities based on B@UNAM's online resources.

In order to promote the learning of English as a second language, CUAED has established agreements with the British Council in Mexico (British Council, 2018) in order to develop an open platform to learn English as a second language. There are also resources to learn Spanish, Italian, and Frenchv.

Communication channels. SUAyED's academic match site is an example of a new or innovative communication channel. An educational social network ${ }^{\text {vi }}$ was developed in order to select teachers with specific leadership and innovation profiles to review the syllabi of B@UNAM's new curriculum. In the future, this social network will also be used for other academic endeavours.

Legacy or new value chain. There are several examples of SUAyED offerings being developed and maintained through exploration of new approaches and innovation. For some time, B@UNAM has been SUAyED's experimental lab, and it now functions as an innovation hub where new ideas, processes, and methodologies are evaluated before they are shared with other schools and university centers. Materials from B@UNAM have also been used to produce support resources for struggling students in one of the F2F systems at UNAMvii, for freshmen in the medicalviii and architectureix areas, and for the general population's lifelong learning purposes. ${ }^{\mathrm{x}}$

B@UNAM's new online courses include a diagnostic assessment of content at the beginning of each week that allows students to use the best trajectory for their unique needs, whether the remedial one that includes prerequisite resources, the regular one, or a track for gifted students. This learning architecture is described in detail in Vadillo (2017).

The process followed at B@UNAM to develop or to update a course is considered an opportunity to explore new ways of delivering content and creating learning experiences. Therefore, the structure as well as the look and feel of each course differs, which also promotes the students' ability to adapt to new learning environments.

Atomization of content through the development of learning units has opened new possibilities to use, recombine, and share content, both among teachers and students of the university and other information consumers in Mexico and other countries. This so-called Lego approach has made it possible to enrich online courses with videos from UNAM's MOOCs as well as with learning bits, brief learning online resources. At the high school and HE levels, dozens of open professional development courses have been deployed. ${ }^{\mathrm{xi}}$ 
During the period 2016 to 2018, important developments and changes have been introduced, instrumental to pursuing CUAED's goal of using open and distance education to promote social inclusion and justice. All B@UNAM content, and content from some undergraduate programs, have been transformed into self-paced learning units; these are fully available for anyone interested in using them. xii

B@UNAM's proposed mission statement, not yet published, now reflects a connectivist, personalized, and learner-empowered position: here each learner builds a strong foundational culture to think about the world and improve it. The proposed vision underscores the institution's connection to society and to the complex environment: each learner expands his/ her talents while developing solutions that foster common good, in complex, tech-enhanced, dynamic and diverse contexts. However, it is clear that internal policies need to be stated in order for this mode of delivery to gain broader acceptance. Moreover, in order to promote inclusion, all programs must comply with universal design for learning principles, which is also a recommendation from the Organisation for Economic Co-operation and Development (OECD), as outlined in their publication (2018) and which B@UNAM lacks.

Permanent revision of practices must be undertaken. As well, ways to reduce the dropout rate and improve timely graduation are important tasks to be considered. In the 2007 version of B@UNAM, for example, a skills map was developed, and all learning activities were aligned to it, so students could practice those skills intensively (Vadillo \& Villatoro, 2009). The curricular map currently under development will seek to foster improved computational, scientific, humanistic, social, and mathematical thinking. Important issues such as digital citizenship (Gleason \& von Gillem, 2018) have been incorporated as a transversal axis of development.

Competitive advantage. In terms of new and emerging technologies, some of UNAM's innovations are described below.

- Artificial intelligence. CUAED is working on content personalization through different strategies such as artificial intelligence (AI). AI should inform changes and should be included to foster deeper comprehension and to improve the learning experience of each student. Teaching and learning practices will change with the inclusion of machine learning, intelligent tutors, and learning analytics. These elements will have an impact not only in personalizing the learning process, but they will also inform CUAED's decision making related to planning, designing, and operating its programs. In Orr et al.'s (2018) survey, only two universities said they were using AI in some way.

- Intelligent tutoring system (ITS) and chatbot. As of January 2018, B@UNAM has been working on the development of an intelligent tutoring system (ITS) to be included throughout its regular courses and learning units by 2020, in order to improve learning outcomes and graduation rates. The tutor is called ADA (an acronym for learning assistant, in Spanish). Analysis of the questions students pose to their tutors indicated that most questions are related to technical aspects, such as "where is content X?" or "how can I download the readings?" These kinds of questions can be answered by a well-trained chatbot, thus freeing time for the human tutor to develop more significant interactions with students. This project is funded by a UNAM innovation office. 
- Agile methodologies. In CUAED, new practices in terms of work dynamics have been established. Adaptive leadership is one of the work strategies recently integrated in B@UNAM in order to promote educational innovation:

Adaptive leadership is an iterative process involving three key activities: (1) observing events and patterns around you; (2) interpreting what you are observing (developing multiple hypotheses about what is really going on); and (3) designing interventions based on the observations and interpretations to address the adaptive challenge you have identified. Each of these activities builds on the ones that come before it; and the process overall is iterative: you repeatedly refine your observations, interpretations, and interventions. (Heifetz, Grashow, \& Linsky, 2009, p. 33)

It is now common practice to ask somebody in the team to play the role of staying in the balcony (i.e., observe teaching and learning processes as they take place) or call on an outsider to provide feedback. These strategies have been an important source of information for improving B@UNAM projects, for instance, by asking young students for their opinion about the design of courses.

Networks. The following are several examples of CUAED operating in non-traditional networks.

- Coursera. Alliances with joint-venture educational models such as Coursera have given CUAED the opportunity to expand education. Coursera only establishes partnerships with selected universities, and UNAM has been recognized as its partner since 2013.

- Revista Mexicana de Bachillerato a Distancia. Public institutions offering high school programs in Mexico have formed a network and journal where they publish items regarding educational models, and their pitfalls and successes. This initiative represents a valuable learning and contribution space.

- NGO. J untos en línea is an example of collaboration between a university and a non-forprofit organization. UNAM provides its online high school program and the NGO supplies an Internet-enabled computer facility for small and underserved communities in rural Mexico which lack a F2F high school. Thus, indigenous students and learners with a very low socioeconomic status have the opportunity to earn a high school diploma.

- Ceibal Foundation, Research and Innovation National Agency of Uruguay (ANII). B@UNAM is part of a project founded by ANII. The aim of the project is to develop an instrument for assessing the evolution of computational thinking (K-12 level), with the collaboration of researchers from four countries.

Profitability and sustainability. Intra-, inter-, and cross-border institutional collaborations and partnerships have been established. Intra-collaboration with other UNAM programs has been intense since 2016, especially with the curricular innovation office (CODEIC) and the ICT general office (DGTIC). 
CUAED has also closely collaborated with Mexico City's Ministry of Education in order to develop and implement several blended and distance programs. Recent projects include the design of a blended and interdisciplinary high school curriculum based on the current problems and context of Mexico City (Vadillo, et al., 2018). Each course portrays one of the city's major problems, and students are expected to build a solution that they can test in a small scale, while using the knowledge they just acquired. This strategy follows the innovation key action from the OECD's Teaching for the Future, which recommends that "teaching related to global challenges needs to be adapted across subjects and go beyond knowledge derived from textbooks. Alternative education methods can be useful in developing these competencies" (Organisation for Economic Co-operation and Development [OECD], 2018, p. 103).

Funding is also obtained from private schools that use B@UNAM's program and online materials, xiii as well as from online professional development courses for private schools.

\section{Discussion}

The analysis as a result of applying the OOFAT model made it possible to assess and map UNAM's openness and flexibility in terms of content, delivery, and recognition, as well as study aspects of its business model. This instrument can help other educational institutions to identify and prioritize innovation strategies, future projects, and alliances.

[The study] can be used by university and college leadership for benchmarking similarities and differences and for cooperative peer learning between institutions. The database of cases and the guidelines for reviewing current strategies, which accompany this study, aim to facilitate this learning and evaluation process." (Orr et al., 2018, p. 8)

As we saw in the Results section, other universities following this content-centered approach share the characteristics of being large and traditional institutions that benefit from the use and creation of OER, and serve economically disadvantaged populations.

Looking at the overall results, the areas of recognition and assessment are in need of more attention at SUAyED. For instance, credentialization is a major challenge to be addressed. Gallagher (2016) described someinnovations in this area such as bootcamps, MOOC-based certificates, and competencybased programs. He goes on to explore the challenges these approaches involve:

The trends are from theoretical to practical, from traditional face-to-face instruction to online, from monolithic to short-form, from instructor-led to self-paced, from static to more adaptive, and from faculty-driven design alone to job-market-aligned. Creating new types of credentials and optimizing new approaches to credential delivery (such as competency-based education and new online models) will require universities to engage in new approaches to design, refresh programs more frequently, focus more intentionally on outcomes, and leverage the still-emerging interdisciplinary field of learning science. The landscape of new university credentials is still in an early phase of development, with most efforts in experimental and pilot form. (Gallagher, 2016, pp. 166- 167) 
CUAED will also need to deal with how to recognize learning through MOOCs. For example, Witthaus et al. (2016) presented a model, based on a traffic light metaphor, with six key elements to be taken into account: (a) identity verification of the learner; (b) suitable, supervised assessment; (c) informative credentials (digital certificates or online badges); (d) quality assurance; (e) awarding credit points; and (f) partnerships and collaboration with institutions or bodies with potential for recognizing student learning. Each of these elements is observed in non-formal, open learning assessment in order to determine how strong they appear, and described by the traffic light metaphor, namely green (very strong presence), yellow (mild presence), or red (no presence).

As well, instruments to facilitate follow-up of the OER materials offered by CUAED, such as the framework by Huang, Hu, and Liu (2017), have been proposed to assess the openness maturity of OERs.

Following their mission, HE institutions carry out academic, intellectual, and formative work incorporating a vast array of perspectives, liberty of thought, critical knowledge, and the continuous search for new knowledge, all while innovating learning and teaching processes. Digital technologies have profoundly changed HE and this movement cannot be stopped. They threaten the controlling and regulating power of curriculum, that began in 1633 at Glasgow University. DeRosa and Robinson (2017) stated that with a more extensive use of OER, the adoption of open educational practices has also increased, and students have begun to develop digital content while building knowledge. Digital technologies also represent a meeting space of diverse communities, and have an important social, cultural, and symbolic content for this university.

At present, current SUAyED programs have an important impact on the campus-based system. This supports the findings of Xiao (2018) who claimed in his recent article that:

Distance education was influenced by campus-based education and in turn influences the latter, leading to convergence of the two modes. To do justice to distance education, its contribution to campus-based education is greater and in more aspects than vice versa. (Xiao, 2018, p. 5)

Other challenges that CUAED, as a public university, must address in the immediate future, some of which are also aligned with those found by Tait (2018), include the following:

- To design socially inclusive models that embrace the cultural diversity of Mexico and overcome the barriers that prevent interaction and articulation of groups, cultures, and perspectives. According to Maassen, Nerland, and Yates (2018) "reconfiguration of knowledge is achieved through the contributions of multiple actors in multiple settings, which serve to connect (or disconnect) knowledge forms and practices in the wider epistemic culture" (p. 197).

- To promote a socially responsible agenda at UNAM in order to contribute to the solution of complex problems of our time.

- To permanently innovate the educational structures that support the academic programs.

- To develop digital technologies that are aligned with the learning demands and nature of the educational projects. 
Despite all the instruments at hand, the innovation path it is not an easy task. It requires the ability to stay in the "the productive zone of disequilibrium" (Heifetz et al., 2009, p. 18), or looking for what Astro Teller, CEO of the Google X projects calls "dynamic stability" (Friedman, 2017, p. 35). This implies learning to work and walk together in contexts of uncertainty, using learning not only as an objective but as way of facing every new initiative.

There are some limitations to this study. Due to the size of SUAyED and the diversity of schools that it comprises, the analysis may have been at times global and in other moments more molecular, so the perspective may lack precision.

\section{Conclusion}

The purpose of this study was to characterize UNAM's SUAyED in terms of its openness, flexibility, and business model, in three distinct time periods. Results show SUAyED has evolved and it can be characterized as currently having a content-focused approach in terms of openness and flexibility, and a prospector-like approach in terms of its business model. SUAyED's main assets are openness and flexibility both in content production and delivery, as well as in support. It must evolve in the areas of recognition and assessment, in order to achieve the so-called OOFAT at the center approach that will allow the system to become integrally open. B@UNAM, the program that was, from the beginning, created with all of the advantages of online education, approximates the desired OOFAT at the center approach. One possible scenario is to provide a pre-university community to address learners' prerequisite knowledge and skills gaps as they enter a HE program, a technology-enriched experience throughout the first semesters, and finally a dual education approach where students profit from faceto-face, online, and blended learning opportunities. 


\section{References}

Berberoğlu, N., \& Berberoğlu, B. (2015). Grouping the mega university countries according to their similarities. Procedia - Social and Behavioral Sciences, 174, 2153- 2159.

https:// doi.org/ 10.1016/j.sbspro.2015.02.015

Bosco, M. D., \& Barrón, H. S. (2008). La educación a distancia en México: Narrativa de una historia silenciosa. [Distance education in Mexico. A narrative of a silent story]. Mexico City, Mexico: Universidad Nacional Autónoma de México (UNAM).

British Council. (2018). Firmamos con la UNAM un convenio para fortalecer la enseñanza del idioma inglés. British Council Mexico [We signed an agreement with UNAM to strengthen the teaching of English. British Council Mexico]. Retrieved from https:// www.britishcouncil.org.mx/ firmamos-con-la-unam-unam-un-convenio-parafortalecer-la-ense\%C3\%Blanza-del-idioma-ingl\%C3\%A9s

Coordinación de Universidad Abierta y Educación a Distancia. (n.d.). ¿Qué es el Sistema Universidad Abierta y Educación a Distancia (SUAyED)? [What is the Open University and Distance Education System (SUAyED)]. Retrieved from https:// suayed.cuaed.unam.mx/que es.php

DeRosa, R., \& Robison, R. (2017). From OER to open pedagogy: Harnessing the power of open. In R. Biswas-Diener \& R. J hangiani, R. (Eds.), Open: The philosophy and practices that are revolutionizing education and science (pp. 115-124). London, UK: Ubiquity Press.

Friedman, T. L. (2017). Thank you for being late. An optimist's guide to thriving in the age of accelerations. New York, NY: Picador.

Gaceta UNAM (1972, February 26). Sistema Universidad Abierta de la UNAM. Algunos aspectos fundamentales [Open University System at UNAM. Several fundamental issues], Gaceta UNAM, special number. Retrieved from http:// acervo.gaceta.unam.mx/index.php/gum70/issue/view/ 784/showToc

Gallagher, S. (2016). The future of university credentials. New developments at the intersection of higher education and hiring. Cambridge, MA: Harvard Education Press.

Gleason, B., \& von Gillern, S. (2018). Digital citizenship with social media: Participatory practices of teaching and learning in secondary education, Educational Technology \& Society, 21(1), 200 212. Retreived from https:// www.jstor.org/ stable/26273880

González-Casanova, P. (1972, February 28). Palabras del Sr. Rector ante el H. Consejo Universitario sobre el proyecto de estatuto del Sistema de Universidad Abierta, [UNAM President's speech before the Honorable University Council on the bylaws project for the Open University System], Gaceta UNAM, 4(4). Retrieved from http:// acervo.gaceta.unam.mx/ index.php/gum70/issue/ view/ 785/ showToc

Graue, E. (2017). Plan de desarrollo institucional 2015- 2019 [Institutional development plan 20152019]. Retrieved from http:// www.rector.unam.mx/doctos/PDI-2015-2019.pdf 
Heifetz, R., Grashow, A., \& Linsky, M. (2009). The practice of adaptive leadership: Tools and tactics for changing your organization and the world. Boston, MA: Harvard Business Press.

Herrera, A.X., Díaz, J ., Soto, J ., Vázquez, F., \& Cervantes, F. (2018). PERSEO Perfiles educativos recurrentes para sistemas de enseñanza optimizada [PERSEO Educational recurrent profiles for optimized teaching systems]. Mexico City, Mexico: Universidad Nacional Autonoma de México (UNAM). Retreived from http:// www.librosoa.unam.mx/handle/ 123456789/ 1823

Huang, R., Hu, Y., \& Liu, X. (2017). How to evaluate the sharing effects of open educational resource projects: An openness maturity analysis framework. In Open Education: from OERs to MOOCs (pp. 149- 160). Berlin, Germany: Springer Berlin Heidelberg. https:// doi.org/ 10.1007/ 978-3-662-52925-6_8

Maassen, P., Nerland, M., \&Yates, L. (2018). Reconfiguring knowledge in higher education: Emerging themes and research avenues. In P. Maassen, M., Nerland, \&L. Yates (Eds.), Reconfiguring knowledge in higher education (pp. 187- 202). Cham, Switzerland: Springer International Publishing. https:// doi.org/ 10.1007/ 978-3-319-72832-2_11

Organisation for Economic Co-operation and Development. (2018). Teaching for the future: Effective classroom practices to transform education, Paris, France: OECD Publishing. Retrieved from http:// dx.doi.org/ 10.1787/9789264293243-en

Orr, D., Weller, M., \& Farrow, R. (2018). Models for online, open, flexible and technology enhanced higher education across the globe - A comparative analysis. Oslo, Norway: International Council for Open and Distance Education. Retrieved from http:// oro.open.ac.uk/55299/1/Models-report-April-2018.pdf

Ruiz, E., Peláez, A., \& Madrigal, A. M. (2015). Reducción de vulnerabilidades y construcción de resiliencia educativa. El caso de la Preparatoria J osé Guadalupe Posada en el barrio de Tepito [Reducing vulnerabilities and construction of educational resilience. The case of the Preparatoria J osé Guadalupe Posada in the Tepito neighborhood], Revista Mexicana de Bachillerato a Distancia, 7(13), 24-35. Retrieved from http:// dx.doi.org/ 10.22201/ cuaed.20074751e.2015.13.64987

Sabath, M. S., García, E., \& González, M. R. (2016). Una experiencia de éxito: el modelo de bachillerato híbrido (B@UNAM) [A successful experience: The blended high school model (B@UNAM)], Revista Mexicana de Bachillerato a Distancia, 8(15), 36- 46. Retrieved from http:// dx.doi.org/ 10.22201/ cuaed.20074751e.2016.15.57371

Sarukhán, J . (1992). Los sistemas de educación abierta y a distancia ante el reto del siglo XXI [Open and distance educational systems facing the challenge of the 21st century]. In Simposium internacional Perspectivas dela educación abierta y a distancia para el siglo XXI. Memorias. Mexico City, Mexico: UNAM.

Tait, A. (2018). Open universities: The next phase. Asian Association of Open Universities J ournal, 13(1), 13- 23. Retrieved from https:// www.emerald.com/insight/ content/ doi/10.1108/AAOUJ -12-2017-0040/ full/html 
Universidad Nacional Autónoma de México. (1983). Pablo González Casanova: 6 de mayo de 1970 - 7 de diciembre de 1972 [Pablo González Casanova: May 6, 1970 - December 7, 1972]. Mexico City, Mexico: UNAM.

Universidad Nacional Autónoma de México. (2018). Agenda estadística UNAM 2018 [Statistical agenda UNAM 2018]. Retrieved from http:// www.planeacion.unam.mx/Agenda/ 2018/ pdf/Agenda2018.pdf

Vadillo, G. (2017). Arquitectura de los cursos de B@UNAM [Course architecture of B@UNAM]. Revista Mexicana de Bachillerato a Distancia, 9(17), 26-31. Retrieved from http:// dx.doi.org/ 10.22201/ cuaed.20074751e.2017.17.64960

Vadillo, G., Macedo, L., \&Terrazas, O. (2017). Comunidad Premed UNAM: un servicio educativo para aspirantes a carreras del área de la salud [Comunidad Premed UNAM: An educational service for prospective students of health sciences]. Revista Mexicana de Bachillerato a Distancia, 9(18), 121-125. Retrieved from http:/ / dx.doi.org/ 10.22201/ cuaed.20074751e.2017.18.64939

Vadillo, G., Rodríguez, M., Bucio, J ., López, S., Herrera-Lasso, A. L., \& Valencia, P. (2018). El Bachillerato híbrido CDMX: Un currículum para la formación de ciudadanía [Mexico City's hybrid high school: A curriculum for citizenship construction], Revista Mexicana de Bachillerato a Distancia, 10(19), 26-34. http:// dx.doi.org/ 10.22201/ cuaed.20074751e.2018.19.64891

Villatoro, C., \&Vadillo, G. (2009). B@UNAM: Interdisciplina y actualización en el currículum integrado de la Universidad Nacional Autónoma de México [B@UNAM: Interdiscipline and updating in the integrated curriculum of Mexico's National University]. Revista Mexicana de Bachillerato a Distancia, 1(special issue), 91-116. Retrieved from: http:// dx.doi.org/ 10.22201/ cuaed.20074751e.2009.Especial.46979

Witthaus, G., Inamorato dos Santos. A., Childs, M., Tannhäuser, A., Conole, G., Nkuyubwatsi, B., \& Punie, Y. (2016). Validation of non-formal MOOC-based learning: An analysis of assessment and recognition practices in Europe (OpenCred). European Union: J oint Research Centre Science Hub. doi:10.2791/809371

Xiao, J . (2018). On the margins or at the center? Distance education in higher education, Distance Education, 39(2), 259-274. doi:10.1080/01587919.2018.1429213

\footnotetext{
i http:// bunam.unam.mx/estructura_curricular.php and https:// propedeutico.cuaed.unam.mx/

ii http:// perseo.cuaed.unam.mx/talentos/login

iii http:// premed.facmed.unam.mx/
} 
iv $\underline{\text { https:// mooc.cuaed.unam.mx/ }}$

v $\underline{\text { https://avi.cuaed.unam.mx/ }}$

vi http://matcha.bunam.unam.mx/

vii http:// www.bunam.unam.mx/vinculacion/

viii premed.facmed.unam.mx

ix prefa.bunam.unam.mx

x http:// uapas.bunam.unam.mx/

xi http:// formaciondocente.bunam.unam.mx?a=b/

xii http:// uapas.bunam.unam.mx/ and https:// uapa.cuaed.unam.mx/

xii https:// www.bunam.unam.mx/ privadas.php

\section{Athabasca}

University

(c) (i) 